\title{
Weather Risk Assessment for Collective Water Supply and Sewerage Systems
}

\author{
Janusz R. Rak ${ }^{1}\left(\mathbb{D}\right.$, Katarzyna Wartalska ${ }^{2, *(\mathbb{D})}$ and Bartosz Kaźmierczak ${ }^{2}$ (D) \\ 1 Department of Water Supply and Sewerage Systems, Faculty of Civil and Environmental Engineering and \\ Architecture, Rzeszow University of Technology, 35-959 Rzeszow, Poland; rakjan@prz.edu.pl \\ 2 Department of Water Supply and Sewerage Systems, Faculty of Environmental Engineering, Wroclaw \\ University of Science and Technology, 50-370 Wroclaw, Poland; bartosz.kazmierczak@pwr.edu.pl \\ * Correspondence: katarzyna.wartalska@pwr.edu.pl
}

check for updates

Citation: Rak, J.R.; Wartalska, K.; Kaźmierczak, B. Weather Risk Assessment for Collective Water Supply and Sewerage Systems. Water 2021, 13, 1970. https://doi.org/ 10.3390/w13141970

Academic Editor:

Katarzyna Pietrucha-Urbanik

Received: 9 June 2021

Accepted: 16 July 2021

Published: 18 July 2021

Publisher's Note: MDPI stays neutral with regard to jurisdictional claims in published maps and institutional affiliations.

Copyright: (c) 2021 by the authors. Licensee MDPI, Basel, Switzerland. This article is an open access article distributed under the terms and conditions of the Creative Commons Attribution (CC BY) license (https:/ / creativecommons.org/licenses/by/ $4.0 /)$.

\begin{abstract}
The weather derivatives market as an instrument of effective weather risk management is still not flexible enough for many industries. The water supply and sewerage industry is sensitive primarily to heavy rainfalls and periods of high and low temperatures: days with heavy rainfall may cause a hydraulic overload of the sewerage systems; on hot days, the water demand increases significantly; on frost days, the risk of water pipe failure grows. The work aimed to summarise methods of weather risk management and propose indices that will help to protect the interests of the water supply and sewerage industry in Poland. Three indices were proposed: a daily precipitation index, frost day index, and hot day index. The frequency of reaching these indices in Poland was verified with the use of meteorological data from 1970-2019, for 19 locations. The non-parametric Mann-Kendall test was used to determine the climate change impact on the exceedance frequency of the proposed indicators. The results showed that the indexes were exceeded in the past once every 6 years, on average. The hot day index was exceeded the least often, but it was the only one with a clear (growing) trend observed.
\end{abstract}

Keywords: weather risk; rainwater; drainage; water supply; climate change

\section{Introduction}

Risk is present in all areas of human activity. We can distinguish between social risk, which is a consequence of human activity, and natural risk, which results from undesirable acts of nature [1,2]. A special type of natural risk is the weather risk, related to the exposure of the company activity to fluctuations of weather factors: temperature, precipitation, wind force, etc. [3,4]. According to the Weather Risk Management Association (WRMA) [5], nearly $60 \%$ of all industries are directly or indirectly dependent on weather conditions. The most frequently mentioned industries directly dependent on the weather conditions are energy [6,7], construction [8,9], tourism [10], agriculture [11], transport [12-14], retail [15,16], and municipal enterprises [17]. In this case, the risk relates to production or production capacity losses occurring as a result of weather phenomena $[18,19]$. The consequence of the weather risk may be, the decreasing value of water production, for instance. The resulting decreasing supply may cause water prices to change (the increase in the price of $1 \mathrm{~m}^{3}$ of water). Price changes are secondary in reference to the primary effects of weather phenomena. Weather factors cause substitutive effects. For example, the lack of precipitation reduces the production of renewable energy (hydropower plants) [20], but sunny weather increases the production of the energy generated by photovoltaic cells [21]. High air temperatures increase the demand for electricity due to the general use of air conditioners [22,23].

Research related to the weather risk are important, especially with regards to progressive climate changes [15]. The increase in average temperatures leads to the rise in the frequency of anomalies and severe weather phenomena that force adaptation measures to be taken respectively to the changes $[24,25]$. In the literature, this topic is widely analysed, 
also in relation to the socio-economic effects of global warming, i.a. in the works [26,27]. In Poland, summer periods are constantly getting closer to the Mediterranean climate. Hot weather is the cause of the reduced production in hydropower (due to droughts) and wind power plants (due to the lack of wind). Increasingly occurring severe storms are a threat to the electric power transmission infrastructure. Low water levels in rivers and reservoirs and high water temperatures cause difficulties in the cooling processes of classic power plants. Consequently, the risk of a summer blackout in Poland (uncontrolled power outage) is increasing. This phenomenon took place on a large scale in April 2008 in Szczecin [15]. In August 2015, Poland was close to a blackout, i.e., an uncontrolled power outage within a large area. The crisis situation was managed due to the import of electric power. It is estimated that an $8 \mathrm{~h}$ blackout would cause losses worth 2.6 billion zlotys [28]. The losses related to floods cannot be underestimated either; for instance, the flood of 2010 resulted in losses worth 12 billion zlotys. Farmers also notice the negative effects of the weather; according to the data from 2018, there were approx. 130,000 crop insurance agreements against damage caused by hail [28].

The knowledge of the changeability of atmospheric conditions in the analysed area is necessary in order to assess the risk of their occurrence. The course of atmospheric phenomena in the preliminary analyses can be described with the use of the normal probability density distribution. Special attention should be paid to the so-called long tails, which play a significant role in statistics [29]. In many cases, rarely occurring events occupy a larger area under the curve (long tail), and thus concisely dominate in terms of population.

Counteracting weather effects is incredibly difficult, but avoiding them is impossible; it complicates the attempts to counteract the weather risk [3]. It has become of major importance to identify appropriate instruments that will allow reducing this type of risk. Hurricane Katrina, which hit the United States, was a milestone for insurance companies and their approach to the weather risk. There has been a risk of non-insurability of certain losses in regions particularly exposed to severe weather events [15].

Derivative weather instruments, also known as weather derivatives, have become the instruments that enable effective management of the weather risk; they allow for the transferring of the risk outside of the enterprise [30,31]. These are bilateral forward contracts, settled on the basis of weather conditions, such as temperature indices, precipitation, and wind speed. This agreement specifies the payment terms between the parties concluding the transaction, depending on the occurrence of specific weather events during the contract time [1]. As the derivatives market is relatively young, it is still not flexible enough. Many industries or enterprises have not yet assessed their exposure to the weather risk, not to mention developed a policy to protect against this type of risk [31].

The main purpose of the thesis is to summarise the knowledge about the weather risk analysis and assessment so that municipal enterprises can effectively start managing the weather risk. The importance of the discussed matter is associated with the concept of sustainable development in terms of climate change. The thesis presents methods of weather risk management and proposes new weather indices for water supply and sewerage systems as entities that are equally sensitive to weather conditions.

\section{Weather Risk}

In order to better understand the problems related to weather risk management, two types of weather risk — due to the impact on the environment—should be distinguished: catastrophic and non-catastrophic [6,19]. The catastrophic risk is a danger related to the occurrence of severe weather phenomena (including floods, hurricanes, and torrential rains), which have a low probability of occurrence. Nonetheless, they cause significant financial losses. The non-catastrophic weather risk is associated with deviations from 'normal' weather conditions. Such phenomena have an impact on the operations of the company, but they do not pose a threat to life or property [32]. 
The terms 'natural disaster' and 'natural catastrophe' are defined separately in Polish legislation and are related to the catastrophic risk. The basic legal act defining the essential concepts associated with the catastrophic risk is the Act of 2002 on the State of Natural Disaster [33]. According to this Act, a natural catastrophe is "an event related to the act of nature, in particular lightning discharge, seismic tremors, strong winds, intense precipitation, prolonged exposure to extreme temperatures, landslides, fires, droughts, floods, ice phenomena on rivers and the sea, lakes and water reservoirs, mass occurrence of pests, plant or animal diseases, infectious human diseases, or the action of another element." A natural disaster is "a natural catastrophe or a technical failure, the effects of which endanger the life or health of a great number of people, large-sized property, large areas of environment, and assistance and protection can be effectively undertaken only through extraordinary measures in cooperation between various authorities and institutions, and specialised services and formations operating under the uniform leadership." The subject of the catastrophic risk is also discussed in the Act of 2007 on Crisis Management [34], which defines additional terms such as a 'crisis situation' or 'hazard and risk maps'. Apart from the two beforementioned acts and the Constitution of the Republic of Poland [35], the group of the most significant legal acts concerning catastrophes and the catastrophic risk includes [36]: the Act on the State of Emergency [37], the Act on Compensation for Property Losses Resulting from the Restriction of Human and Civil Rights during the State of Emergency [38], the Act on the Safety of Mass Events [39], the Water Law [40], the Decree on Provisions for Fighting Natural Disasters [41], the Fire Protection Act [42], the State Medical Rescue Act [43], and the Environmental Protection Law [44]. In addition to the aforementioned acts, there are also many executive orders, such as the Regulation of the Council of Ministers on Detailed Rules for the Participation of Subunits and Units of the Armed Forces of the Republic of Poland in Preventing or Removing the Consequences of the Natural Disaster [45].

The non-catastrophic weather risk describes the exposure to financial profits or losses as a result of the variability of weather conditions that do not lead to natural catastrophes $[1,46]$. The scale of deviations of weather conditions from their average, normal state is not as significant as in the case of catastrophic phenomena. Usually, in the literature, the term 'weather risk' is equated with the non-catastrophic weather risk [19].

Due to the category of occurring weather events, geophysical (earthquakes, volcanic activity, and tsunamis), meteorological (storms), hydrological (floods and landslides), and climatological (extreme temperatures, droughts, and forest fires) risks can be distinguished [47]. It is worth noting that different economic entities are sensitive to different weather factors. For example, the energy sector is sensitive to temperature changes, while the activity of hydropower plants is affected by precipitation levels [46]. Hence, basic categories of weather risk depend on the type of atmospheric phenomenon. There are risks of [19]: air temperature, rainfall, snowfall, wind speed, and humidity.

The specific features of the weather risk result from the analysis of the nature of atmospheric phenomena. The main features are $[19,48,49]$ :

- Lack of cash instruments that would protect entities against the weather risk effects;

- Local character of risk, which limits weather phenomena to a specific geographical territory;

- Seasonality, which is the variability of weather phenomena over time (seasonal nature of the phenomena related to, i.a. the seasons of the year);

- Occurrence of the so-called fat tails phenomena with a low probability of occurrence are associated with high losses;

- Difficulty in transferring atmospheric phenomena to financial markets;

- Difficulty in local forecasting and determining the effects of atmospheric phenomena (various nature of changes, continuous or precipitous); they require the use of different derivatives (futures for continuous options and binary options for precipitous ones);

- Extensive monitoring infrastructure is required to measure weather phenomena;

- No correlation with other risk categories of operating a business. 
In the past, many companies did not consider weather risk management, but only tried their best to handle the negative consequences of unfavourable weather. Systematic weather risk management is becoming a necessity, resulting from the trend of climate changes [6]. Natural catastrophes, occurring more frequently, require increasing the effectiveness of risk management. The effectiveness of actions in this area is determined by reliable knowledge about the risk, not the intuitive information or ideas about it.

In response to the growing danger of natural catastrophes, the member states of the UN concluded the international Sendai Framework agreement in 2015 [50]. The main objective of the agreement is to increase safety related to the hazard of weather phenomena in the next 15 years (the agreement covers the period 2015-2030) [51]. The agreement itemises four priority areas of action:

- Understanding the risk connected with natural disasters;

- Increasing readiness to manage the risk of catastrophes;

- Investing in methods of action aimed at reducing the risk in the future (including early warning systems, protection of production assets, and increasing the security and functionality of critical infrastructure);

- Increasing catastrophe preparedness for a faster response to these phenomena.

Actions taken under the Sendai agreement are to be in line with the 2030 Agenda and the Sustainable Development Goals (SDGs) [52]. In Poland, the body coordinating the 2015-2030 action program on limiting the risk of natural catastrophes is the Government Centre for Security.

In Poland, activities are conducted in order to manage the risk of catastrophes. One of these activities is running the Agricultural Drought Monitoring System in Poland (ADMS) by the Institute of Soil Science and Plants Cultivation-National Research Institute (ISSPC-NRI) on behalf of the Ministry of Agriculture and Rural Development. Its task is to indicate areas for which crop losses related to droughts have been recorded [53]. The IT System of the Country Protection (ITSCP) is aimed at the systemic protection of the society, economy, and the environment against extraordinary dangers, especially floods. The project is implemented by the Institute of Meteorology and Water Management (IMWM) in cooperation with the Head Office of Geodesy and Cartography, the National Water Management Authority, and the Institute of Communication [54]. The Ministry of Environment developed urban plans for adaptation to climate changes in 44 Polish cities (44MPA). The project aimed to assess the sensitivity of climate changes, in order to plan adaptation measures adequate to the identified threats, in 44 cities with over 100,000 inhabitants which, in turn, constitute approximately $30 \%$ of the whole Polish population [55]. This is particularly important when we realise that public and private property is condensed mainly in cities. Moreover, in recent years, there has been a noticeable increase in the number of people living in Polish cities (for instance, this percentage was $40 \%$ in 1950 and $62 \%$ in 2010, while the forecast for 2050 is equal to $71 \%$ of the Polish population). Three urban agglomerations are of the greatest exposure in terms of the natural catastrophe: Warsaw, Kraków, and the Tri-City [28]. Raising the issue of risk management in Poland, it is also worth mentioning the Alert of the Government Centre for Security (GCS; pol. RCB), which is the system of notifying the population of the country about hazards. The GCS receives information about potential threats from ministries, services, offices, and central institutions (the Institute of Meteorology and Water Management) of Polish provinces. The alert is sent via SMS from all mobile network operators.

Weather risk management in the context of protection against catastrophic effects has been known for years. Available risk management strategies can be divided into four groups of actions, regardless of the type of the weather risk. These are: avoidance and reduction (physical methods), and risk retention and transfer (financial methods) [15]. The avoidance strategy concerns evading all risk-related activities, especially in relation to natural catastrophes. A company using this strategy discontinues selling or manufacturing in bad weather areas. This goal is mainly achieved by including threats in spatial development plans [6]. Risk reduction is the use of methods that decrease the probability of 
risk occurrence and minimise damage when the risk occurs. This happens, i.a. through the use of resistant construction solutions of various types of buildings. For example, in relation to the flood risk, it is the construction of retention basins and flood embankments (an attempt to control nature). Moreover, early warning and crisis management systems are being developed [47]. Risk retention requires covering any losses through using own funds. If it is a deliberate action, it requires the creation of an appropriate financial reserve in order to cover the losses. If it results from a lack of knowledge, it leads to bankruptcy or even professional or criminal liability. The risk transfer consists in its transmission to a specialised entity, which is an insurance company. The insurer usually retransfers the risk to the reinsurers. In the USA, it is possible to transfer the catastrophic risk to capital markets. The selection of the appropriate strategy (or their combination) should be preceded by risk identification (identification of hazards, their potential impact, and probability of occurrence) [15].

Instruments intended to protect economic sectors against weather risk can be divided into two main groups that are used depending on the type of risk: insurance and derivatives. Insurance is an adequate solution in the event of extreme weather events [1]. They offer long-term protection to enterprises. 129 insurance companies from 29 countries cooperate with each other by co-financing the weather risk research and integrating the weather risk into the investors' decision-making process [47].

The tasks of insurers in the risk management system include [28]:

- Collecting loss data resources to understand and identify risks, and their financial implications;

- Rewarding for activities contributing to the risk reduction, i.e., reduction of financial losses, where skillful risk management results in lower insurance premiums;

- Controlling losses and providing financial assistance in an effective manner;

- Supporting the resource recovery after extreme events.

The tasks of the state administration related to risk management include [28]:

- Creating and sharing maps of natural catastrophes;

- Conducting an appropriate spatial development policy;

- Adapting construction standards to new hazards and strengthening the role of construction supervision;

- Prevention and education.

Events with a relatively high probability of occurrence, generating high losses, can be insured through public-private partnerships. Cooperation may consist in prevention, i.e., reducing the probability of the occurrence of an extreme event, and mitigation, limiting the effects of an event after its occurrence [28].

Long-term solutions proposed by insurers are often insufficient for companies in many industries that are exposed to even short-term fluctuations in weather conditions; any deviation from the average can reduce profits. Financial solutions that most effectively protect against the non-catastrophic weather risk are derivative weather instruments (derivatives).

The creation of derivatives is associated with the demonopolisation of the energy sector in the USA. Competition, associated with it, has generated weather risk management processes. In 1996, the first contract was signed between Enron and Koch Energy. The weather agreement concerned the protection against low temperatures $[16,56]$. The first contracts were concluded on the basis of individual arrangements between the entities on the over-the-counter (OTC) market. However, in 1999, standardised weather derivatives were introduced to exchange trading by the Chicago Mercantile Exchange (CME) [18,31]. Currently, the OTC market and CME are developing highly dynamically [48]. On the CME, weather contracts are issued by 11 European cities: Amsterdam, Barcelona, Berlin, Essen, London, Madrid, Oslo, Paris, Prague, Rome, and Stockholm [57].

Derivatives differ from insurance in many aspects. The purpose of insurance is to protect against phenomena with a low probability of occurrence that cause high losses and are associated with incredibly high risk. Weather insurance requires documenting 
the loss suffered and enabling the compensation in the form of a one-time payment, often without an appropriate proportion to the losses incurred. Derivatives, in turn, protect against relatively low risk, i.e., against events with a high probability of occurrence that cause low losses. Contrary to insurance, the compensation payment is made in proportion to the scale of the adverse event each time when the value of the weather index exceeds the assumed base value [1].

The value of weather derivatives is strictly dependent on the value of defined weather factors [16]. Depending on the weather factor influencing the company revenues, the following types of weather futures contracts can be distinguished on the market nowadays [19]: temperature-dependent contracts, rainfall contracts, snowfall contracts, frost contracts, and hurricane contracts. The most numerous group (over $85 \%$ of weather derivatives) consists of those based on temperature indices. There are three basic types of indices of this sort [16]:

- HDD temperature index (heating degree days), which is the heating season index, and CDD (cooling degree days), which is the summer season index (one of the first temperature indices, still the most popular, mainly in the USA);

- Minimum, maximum, or average temperature level in a particular period (dominating the European market);

- Number of critical days on which the temperature level was exceeded.

Derivative groups based on non-temperature indices are also important in terms of reducing the weather risk. The most numerous group of non-temperature indices consists of rainfall and snowfall indices. The existing instruments based on the rainfall index are among the youngest on the financial market; therefore, there is relatively little information in the literature on these derivatives [58]. These indices are currently constructed as the monthly average amount of precipitation in terms of 10 American cities. According to past contracts, each inch of rain (1 index point) is usually worth USD 500 [19,58,59]. Rainfall contracts are available in two variants. The first one, based on a monthly index, consists of selecting one month from the period from March to October. The second option, based on a seasonal index, allows the selection of two to eight consecutive months from the same period (May-October) [58]. The greatest interest in rainfall contracts is shown by public utility companies, organisers of sports events, outdoor concerts, and theme parks [19].

Frost contracts are based on the number of frost days occurring in the period from the first Monday in November to the last Friday in March. The contract was designed for the Dutch construction market; however, it is listed on the CME market. A frost day is considered to be a day in which at least one of three conditions are met: the temperature at $7.00 \mathrm{a} . \mathrm{m}$. is lower than or equal to $-3.5^{\circ} \mathrm{C}$; the temperature at $10.00 \mathrm{a} . \mathrm{m}$. is below or equal to $-1.5^{\circ} \mathrm{C}$; the temperature measurements for 7.00 a.m. and 10.00 a.m. are lower than $-0.5^{\circ} \mathrm{C}[19]$.

An option listed on the CME may be an example of the hurricane contract. It is to ensure the possibility of protection for entities that have already used instruments securing against the catastrophic risk (e.g., insurance) where a particular region has been hit by a hurricane again. This type of contract differs from the others because it is associated with a catastrophic phenomenon [19].

Currently, different types of weather derivatives are available [60,61]:

- Futures contracts;

- Forward contracts;

- Weather options (cap, floor, or collar [16]);

- Swaps.

Futures contracts are standard form agreements (with specific conditions) creating an obligation to exchange a certain amount of the underlying instrument at a predetermined price and a given date. They are settled in cash [18].

Forward contracts are non-standard agreements concluded on non-regulated markets. It is associated with the risk of failure to fulfill the contract by one of the parties [60]. 
Agreements of this type oblige one party to deliver and the other party to receive a fixed quantity of the underlying instrument at a specified price and within a given period [18].

Weather options are instruments that exist in both stock exchange and over-the-counter markets [16]. Contracts of this type give the purchaser the right, not the obligation, to buy (call option) or to sell (put option) a specified quantity of the underlying instrument at a fixed price on a given date [18]. Often used options are cap variants, with an upper limit level (used when the index exceeds a fixed value), and floor variants, with a lower limit level (used when the index is below a given value). If both strategies are used simultaneously, this combination is called the collar strategy. This option is characterised by the lack of payment when the index values are within a certain range; one side benefits when the index rises above the top of the range, and the other side benefits when the index falls below the bottom of the range.

The last group consists of swap contracts. They involve an exchange between the parties on agreed terms of future payments; the two parties share the risk. One party earns when the weather index exceeds a certain value, while the other party earns when the index drops below this level. The finances of the parties stabilise when there are changes in weather conditions [18].

Each weather transaction should be developed with the use of the following parameters [2,31]:

- Type of the contract;

- Contract period (i.e., the start and end date of its validity);

- Base index (index structure representing one or more weather variables, which is the basis for the financial settlement of the contract);

- Primary and backup weather station (source of data necessary to calculate the desired weather index);

- Payout function (an instrument and monetary value of the index point).

Weather forecasting is crucial for both the supply and demand on the derivatives market [30]. Brokers use forecasts to make adjustments to the price of the instrument. In turn, customers (business entities) use forecasts to make decisions. Among the meteorological forecasts, seven categories can be distinguished, depending on the time horizon for which they are formulated [60]. These are the forecasts [62]: current (with the time horizon $\leq 2 \mathrm{~h}$ ), one-day (12-24 h), short-term (24-72 h), medium-term (3-14 days), seasonal (1-3 months), long-term (6 months-2 years), and multiannual (over 2 years).

A defined weather index enables the valuation of the insurance value. Therefore, any analysis of the weather risk in an enterprise requires a large meteorological database. The problem of the quality, availability, and cost of weather data differs from country to country, which is important from the point of view of the underlying risk (usually lower in OTC weather derivatives compared to the stock market). In this context, the availability of reliable historical meteorological data of a given region remains one of the most important barriers to the wider use of weather derivatives [15]. In the case of Polish conditions, obtaining meteorological data is occasionally problematic due to the high cost of acquiring such data [60]. The development of the weather derivatives market determines the development of technologies and information used in weather stations, which will allow for the continuous transmitting of the meteorological data [63].

Currently, in Poland, the only company that conducts weather transactions is Consus SA, whose headquarter is located in Torun, and whose regional offices are located in Łódź, Katowice, and Szczecin. Its specialty is the sale of derivatives in Poland and Europe. As the only entity in Poland, it belongs to the Weather Risk Management Association (WRMA) [63].

Derivative weather instruments can be a good tool for securing the income of economic entities such as waterworks and sewerage companies. To illustrate how a weather derivative works, it is best to refer to the temperature index. When the municipal waterworks company is not able to supply the amount of water required by the demand on hot days (the wells do not guarantee the indispensable capacity), the water supply 
restrictions cause financial losses. A waterworks company may conclude an agreement for a specified period (e.g., from June to September) for each day when the temperature exceeds a given level (e.g., $25^{\circ} \mathrm{C}$ ). As a result, the company will obtain compensation in the form of the agreed amount and earn income despite the excessively high temperature in a given period. The contract can be extended with possible compensation to farmers for restrictions or the lack of water supply. For waterworks and sewerage companies to be able to effectively protect themselves against the weather risk, creating models of the valuation of weather instruments, as well as the indication of weather indices adequate for this industry, becomes a matter of priority.

\section{Environmental Factors Affecting Water Supply and Sewage Systems Operation}

World literature increasingly discusses often the failure rate of water and sewage systems, the causes of which are related to both intrinsic factors (age of pipes [64,65], material $[66,67]$, material defects, errors in the process of building or designing the network [68]), environmental factors (e.g., soil freezing around pipes [69] or climatic and ground conditions, including climate change [70-73]), and operational factors (internal water pressure and previous failures) [74].

Increased water main breaks are experienced in colder seasons [75,76]. Opinions on the causes of this phenomenon are divided. Some observers claim that failures occur when there are sudden and prolonged changes in water and air temperatures, which are typically in late fall to early winter and late winter to early spring periods. Others associate the failure rate of the network with the water temperature, not the air temperature, while still others claim that it is the temperature difference between the water in the pipe and the ground that has the greatest impact on the occurrence of damage to water pipes [64]. Rajani and Tesfamariam [77] observed an increased failure rate of water supply networks in the case of large temperature differences between the water in the conduit $\left(1-2{ }^{\circ} \mathrm{C}\right)$ and the adjacent ground $10-12^{\circ} \mathrm{C}$ ).

Research on the impact of temperature on piping failures has been conducted for years. The study [64] mentions, inter alia, research by Walski and Pelliccio [78], who connected pipe damage to air temperature and the age of pipes using the regression model:

$$
N(t, T)=N\left(t_{0}\right) e^{A t} e^{B T}
$$

where $t$ is the age of the pipe, $N\left(t_{0}\right)$ is the breaks per pipe length at the year of installation, $T$ is the average air temperature in the coldest month, and $A, B$ are constants.

In the UK, the most reliable weather variable turned out to be frosty days; an increase in the number of damage occurrences by 4 to $10 \%$ was observed with each additional frost day during the month [73]. Similarly, in [75], the freezing index turned out to be the most adequate indicator in relation to the failure rate of water supply networks.

In the study [64], the impact of temperature changes on the pipe cracking rate was analysed. It was found that variables based on temperature, such as the average air temperature, maximum increase and decrease in air temperature, as well as the rate of its increase and decrease over a certain time (number of days), significantly affect the network's failure rate. Interestingly, a decrease in the intensity of the air temperature change and a decrease in the water freezing index lead to an increase in predicted breaks.

In the study [79], based on a failure rate analysis of the water supply system located in the south-eastern part of the Polish river Wisloka, it has been proved that the failure rate is influenced by seasonal conditions, and the increased failure rate is noted in the winter months, which is related to the low temperature; that is, the freezing of ground around the pipes or the repeated freezing of water in the line. Increased failure rates were observed for February, August, September, and December. A high failure rate in the summer months may be caused by frequent earthworks carried out during this period [79]. Similar results were obtained by Pietrucha-Urbanik [80], who observed an increased failure frequency of the water supply network in the area of Krosno (Poland) in autumn and winter. 
Newport [81] found in his research in the UK that pipe failures coincide with the presence of cumulative degrees of frost in winter. This is due to frost penetration resulting in increased earth loads, but also occurring more frequently during very dry periods in the summer, when soil shrinkage leads to increased shear stress exerted on the pipe. The seasonal occurrence of failures in municipal networks is also confirmed by other studies $[71,76,82,83]$.

The publication [73] investigates a correlation between weather parameters (air temperature, drought, and wind) and the failure of pipes in water networks in the Netherlands. The temperature has the greatest impact on pipe damage, followed by periods of drought, while wind has not been found to affect pipe failure. The increased failure rate on hot days may be due to a lowering of the groundwater level, which leads to additional external loads on the conduit due to the subsidence or shrinkage of the soil (bending stress results in a loss of support under the conduit). This is particularly characteristic of expansive soils, and the effects are visible mainly in pipes made of rigid materials (e.g., cast iron), less frequently in flexible pipes (e.g., PVC-U) [71]. Another disadvantage is the increased water intake from the mains in hot weather, which results in greater internal loads on the pipe (due to increased pressure and/or water flow velocity). Further, during hot periods, the soil temperature may rise, causing thermal stresses (due to temperature differences between the soil and the water inside the pipe).

It is worth adding that prolonged dry periods in the summer season also affect the failure frequency of pipes in the winter season. Long-term dry weather leads to soil with a low latent heat capacity, which results in deeper frost penetration into the soil during winter $[83,84]$. Data on groundwater levels are usually not available. Thus, instead of the soil moisture index, the cumulative rain deficit [73,74], or the antecedent precipitation index (API) $[71,73]$ is used. Studies have shown that the greater the API during hot days (i.e., the greater the soil moisture), the lower the risk of pipe failure [71].

The topic of failure rates in gravity sewage systems was also discussed, incl. in the study [85], which tested the corrosivity in concrete channels. The formula [86] is used to estimate the corrosivity coefficient in gravity systems, in which one of the parameters is temperature:

$$
Z=B O D_{5} \frac{P / b}{s^{0.5}(35.314 Q)^{0.33}} 1.07^{T-20}
$$

where $B O D_{5}$ is the biological oxygen demand during 5 days $\left(\mathrm{g} \mathrm{m}^{-3}\right.$ of $\left.\mathrm{O}_{2}\right), P$ is the wetted pipe wall perimeter $(\mathrm{m}), B$ is the pipe width at sewage surface $(\mathrm{m}), T$ is the temperature $\left({ }^{\circ} \mathrm{C}\right), s$ is the slope $\left(\mathrm{m} \mathrm{m}^{-1}\right)$, and $Q$ is the flow $\left(\mathrm{m}^{3} \mathrm{~s}^{-1}\right)$.

A compendium criteria, [87] developed at the Institute of Meteorology and Water Management-National Research Institute (IMWM-NRI), for issuing warnings against heavy rainfall, among others, have been described for services involved in crisis management. A 3-level scale has been proposed: from 30 to $50 \mathrm{~mm}$ in $24 \mathrm{~h}$ (risk level 1), from 50 to $90 \mathrm{~mm}$ in $24 \mathrm{~h}$ (risk level 2), and over $90 \mathrm{~mm}$ (risk level 3).

In the first case (rainfall from 30 to $50 \mathrm{~mm}$ ), local flooding and flooding of lower set areas and interiors occur, and there are difficulties in pedestrian and road traffic. In the second case (rainfall from 50 to $90 \mathrm{~mm}$ ), there is surface flooding of lower set areas and interiors, and the first major damage to infrastructure equipment. In the third case (rainfall over $90 \mathrm{~mm}$ ), storm drains and sewer pipe cross-sections do not manage to collect the excessive amounts of water, streets become channels of "rainfall rivers", and catastrophic damage to infrastructure may occur.

The studies on the failure frequency of water supply and sewage networks presented in the aforementioned publications indicate that among the weather factors influencing the failure frequency, the most important are the temperature and the amount of precipitation. Although the influence of water or ground temperature on the networks' failure rate is indicated, the fact is that these data are difficult to access, hence a much better solution in the case of using weather derivatives for the water and sewage industry is to link the risk 
of failure with the temperature of the outside air, especially as many studies have shown that air temperature data are usually sufficient to predict water supply interruptions from water supply networks [64].

\section{Materials and Methods}

The water supply and sewerage industry is sensitive primarily to heavy rainfalls and periods of high and low temperatures. During days with a high rainfall intensity, the phenomenon of the hydraulic overload of the rainwater drainage system occurs and may cause sewer flooding, resulting in flooding streets and basements, land flooding, or stormwater discharges in the case of combined sewerage [88]. On hot days, the water demand increases significantly (over the capacity of water intakes), and on frost days, the risk of failure of water pipes grows [89-91]. Therefore, based on a review of the literature regarding the failure rate of water networks, and more specifically the weather factors affecting the networks' failure rate, and further taking into account the meteorological conditions of the majority of Poland, the following weather indices are proposed for the water and sewerage industry (excluding mountain areas):

- Daily precipitation index (for rainwater and combined sewerage systems) if the daily precipitation exceeds $50 \mathrm{~mm}$;

- Frost day index (for water supply systems) if the average temperature is lower than $-15^{\circ} \mathrm{C}$ for the next 5 days;

- Hot day index (for tap water consumption) if the average temperature is higher than $25^{\circ} \mathrm{C}$ for the next 5 days.

Determining the threshold values for the above-mentioned indicators is difficult due to the multitude of factors influencing the occurrence of failures, related not only to weather conditions but also to the technical condition of the network, its age, or material. Factors influencing the failure rate of water supply and sewage systems are presented in Section 3 of the paper. Threshold values proposed in this study have been defined for Polish climatic conditions, taking into account the results of the failure frequency analyses of water supply and sewage systems presented in the literature.

For the daily precipitation index, the criteria for issuing a warning against heavy rainfall in Poland [87] were taken into account. In particular, the lower limit of the rainfall amount for risk level 2 was adopted as a threshold value, with the daily precipitation exceeding $50 \mathrm{~mm}$, where surface flooding of lower set areas and interiors and the first major damage to infrastructure equipment occur.

For the frost day index, the assumption was taken into account that cold periods may result in thermal stresses caused by temperature differences between the soil and water in the pipe or freezing and melting of moisture in the ground surrounding the pipe. For such a situation to occur, the air temperature must remain below $0{ }^{\circ} \mathrm{C}$ for a longer time. The studies presented in [73] revealed that at a temperature of $-10^{\circ} \mathrm{C}$, the frequency of failure is much higher than for the temperature of $-5^{\circ} \mathrm{C}$. With regards to this, the average temperature lower than $-15{ }^{\circ} \mathrm{C}$ for the next 5 days was adopted as the frost day index.

For the hot day index, the assumption was taken into account that hot periods may result in thermal stresses caused by temperature differences between the soil and water in the pipe or thermal expansion of the pipe in a longitudinal direction. Furthermore, the water demand is higher in periods of high temperature, and, as a result, larger differences in internal pressure over the day and night might occur [73]. At the same time, it is often assumed that the comfortable temperature range for people is from 17 to $24{ }^{\circ} \mathrm{C}$. With regards to this, the average temperature higher than $25^{\circ} \mathrm{C}$ for the next 5 days was adopted as the hot day index.

These proposed indices should be verified in terms of the frequency of reaching them in Poland. For this purpose, the meteorological data from 19 stations of the Institute of Meteorology and Water Management-National Research Institute (IMWM-NRI) from years 1970-2019 (50 years of observation) were derived. The data derive from meteorological stations located in Białystok, Gdańsk, Gorzów Wielkopolski, Katowice, Kielce, Kosza- 
lin, Kraków, Lublin, Łódź, Olsztyn, Opole, Poznań, Rzeszów, Suwałki, Szczecin, Toruń, Warsaw, Wrocław, and Zielona Góra (Figure 1).

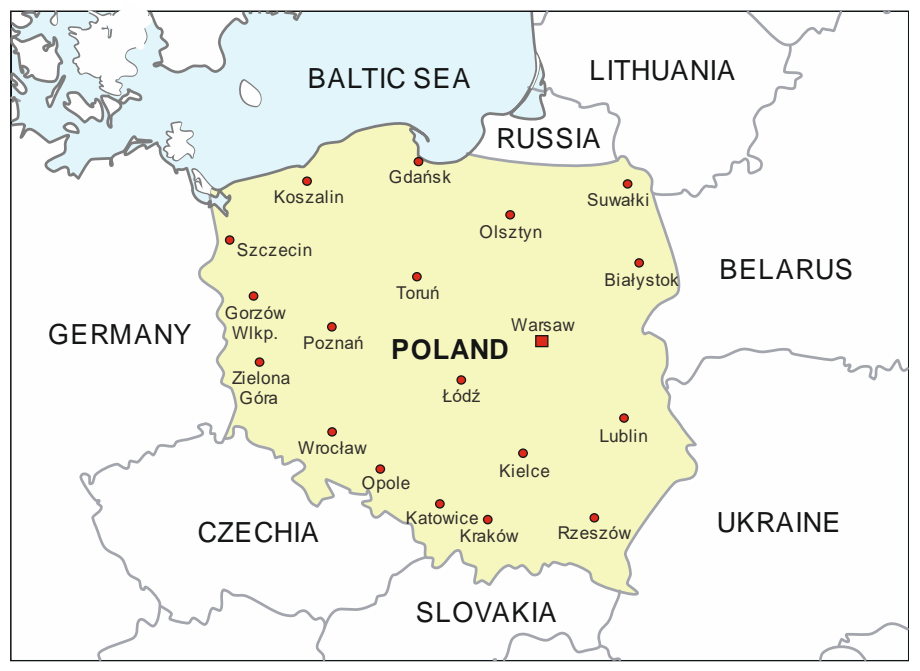

Figure 1. Location of measuring stations.

Additionally, taking into account the observed climate change [92], the direction of changes in the occurrence frequency of the proposed weather indices should be determined. This research employs the non-parametric $\mathrm{M}-\mathrm{K}$ test for detecting trends in hydrological time-series, widely applied in hydrological studies [93-95]. This test uses rank correlation statistics to answer the question as to whether the values measured in the time series present a statistically significant increasing or decreasing trend. The $\mathrm{M}-\mathrm{K}$ test analyses the sign of the difference between successive elements of the time series, where each new value is compared to all previously measured values [96,97]. Changes (increases or decreases) are considered statistically significant at a level above $95 \%$.

\section{Results}

\subsection{Daily Precipitation Index}

Intense rainfall occurs in Poland especially during the summer months between June and August. Figure 2 shows maximum daily fall amounts recorded between 1970 and 2019 on each of the meteorological stations analysed in the paper, in the form of a heat map.

Despite the precipitations being highly variable in space and time, the year 1989 can be singled out, in which the average of the maximum daily precipitation amounts is the lowest, being $28.6 \mathrm{~mm}$, and the daily precipitation index $(50 \mathrm{~mm})$ was reached only in one of the 19 analysed cities: Kraków $(50.9 \mathrm{~mm})$. In 1971, 1973, and 1986, the daily precipitation index was reached at none of the analysed locations. The highest average of the maximum daily precipitation amounts was recorded in 2010, being no fewer than $47.3 \mathrm{~mm}$, and the daily precipitation index was reached at eight locations (in Białystok, Gdańsk, Katowice, Kraków, Opole, Rzeszów, Suwałki, and Wrocław). In 1970, the daily precipitation index was reached at nine locations, with the average of all of the 19 cities being $45.3 \mathrm{~mm}$.

The absolute maximum daily precipitation, which was no fewer than $155.2 \mathrm{~mm}$, was recorded in Kielce in 2001, whereas the minimum one (of the maximum ones) was only $12.3 \mathrm{~mm}$ and was recorded in Poznan in 1992. In the case of each of the analysed locations, there were years during which the precipitations exceeded the daily precipitation index proposed. Such precipitations occurred most frequently in Katowice, Koszalin, and Kraków at 16 times each (for 50 years of observations), whereas they occurred the least frequently in Szczecin (5 times) and Gorzów Wlkp., Poznań, and Warsaw (6 times each). In none of the analysed locations were any statistically significant trend of change recorded in the maximum in a year of daily precipitation amounts (at the level of statistical significance of 95\%). The calculation results are juxtaposed in Table 1. 


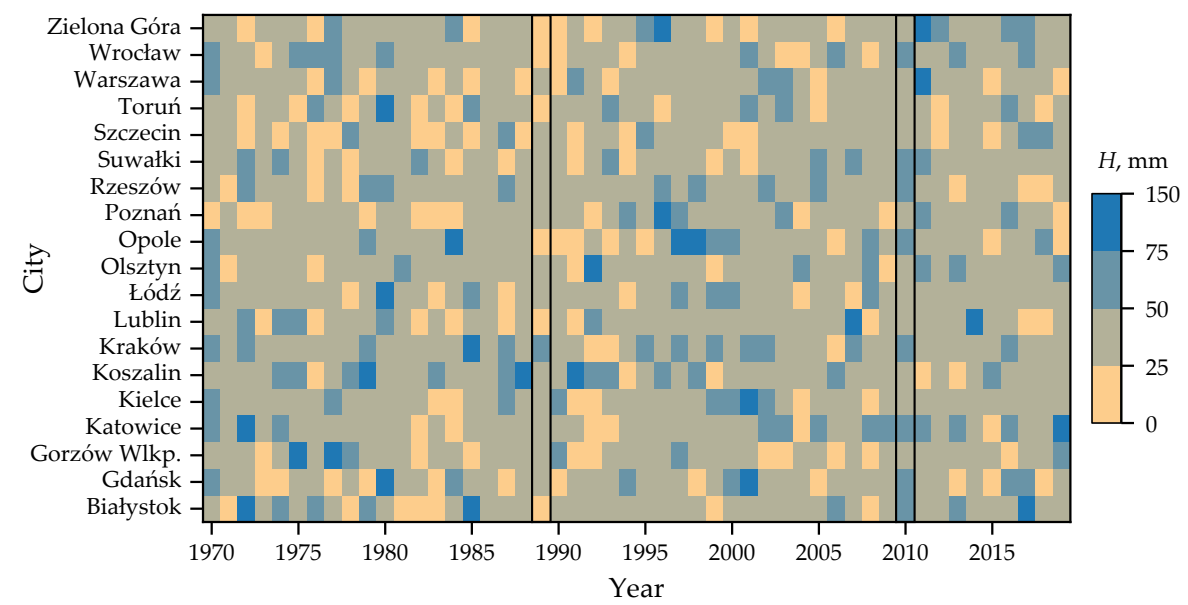

Figure 2. Maximum daily precipitation $(H, \mathrm{~mm})$ recorded between 1970 and 2019.

Table 1. Analysis of the daily precipitations between 1970 and 2019.

\begin{tabular}{|c|c|c|c|c|c|c|}
\hline \multirow[b]{2}{*}{ City } & \multicolumn{3}{|c|}{ Maximum Precipitation Amounts } & \multicolumn{2}{|c|}{ Trend } & \multirow{2}{*}{$\begin{array}{c}\text { Number of Days } \\
\text { with Precipitation above } 50 \mathrm{~mm}\end{array}$} \\
\hline & $\begin{array}{l}\text { Min, } \\
\text { mm }\end{array}$ & $\begin{array}{l}\text { Mean, } \\
\text { mm }\end{array}$ & $\begin{array}{l}\text { Max, } \\
\text { mm }\end{array}$ & Yes/No & $\begin{array}{c}\text { Slope, } \\
\text { mm/Decade }\end{array}$ & \\
\hline Białystok & 16.6 & 37.7 & 90.6 & No & - & 12 \\
\hline Gdańsk & 17.4 & 36.9 & 118.0 & No & - & 8 \\
\hline Gorzów Wlkp & 17.6 & 35.8 & 77.4 & No & - & 6 \\
\hline Katowice & 19.2 & 42.0 & 81.6 & No & - & 16 \\
\hline Kielce & 17.0 & 38.8 & 155.2 & No & - & 9 \\
\hline Koszalin & 21.1 & 45.2 & 101.3 & No & - & 16 \\
\hline Kraków & 17.8 & 40.8 & 87.4 & No & - & 16 \\
\hline Lublin & 16.4 & 37.7 & 90.0 & No & - & 7 \\
\hline Łódź & 14.2 & 36.2 & 99.8 & No & - & 8 \\
\hline Olsztyn & 18.4 & 37.9 & 98.9 & No & - & 8 \\
\hline Opole & 20.0 & 39.9 & 99.0 & No & - & 10 \\
\hline Poznań & 12.3 & 34.4 & 85.7 & No & - & 6 \\
\hline Rzeszów & 14.0 & 37.8 & 65.2 & No & - & 12 \\
\hline Suwałki & 15.1 & 35.6 & 66.8 & No & - & 8 \\
\hline Szczecin & 14.4 & 33.0 & 74.3 & No & - & 5 \\
\hline Toruń & 17.0 & 36.8 & 101.6 & No & - & 8 \\
\hline Warszawa & 17.0 & 35.3 & 75.8 & No & - & 6 \\
\hline Wrocław & 17.2 & 39.5 & 74.4 & No & - & 11 \\
\hline Zielona Góra & 14.7 & 37.2 & 89.0 & No & - & 8 \\
\hline
\end{tabular}

Out of the analysed localities, it is Szczecin $(33.0 \mathrm{~mm})$ that is distinguished by the lowest average of the maximum daily precipitation amounts, and Koszalin $(45.2 \mathrm{~mm})$ is distinguished by the highest one. A set of the maximum daily precipitation amounts in those cities between 1970 and 2019 is shown in Figure 3.
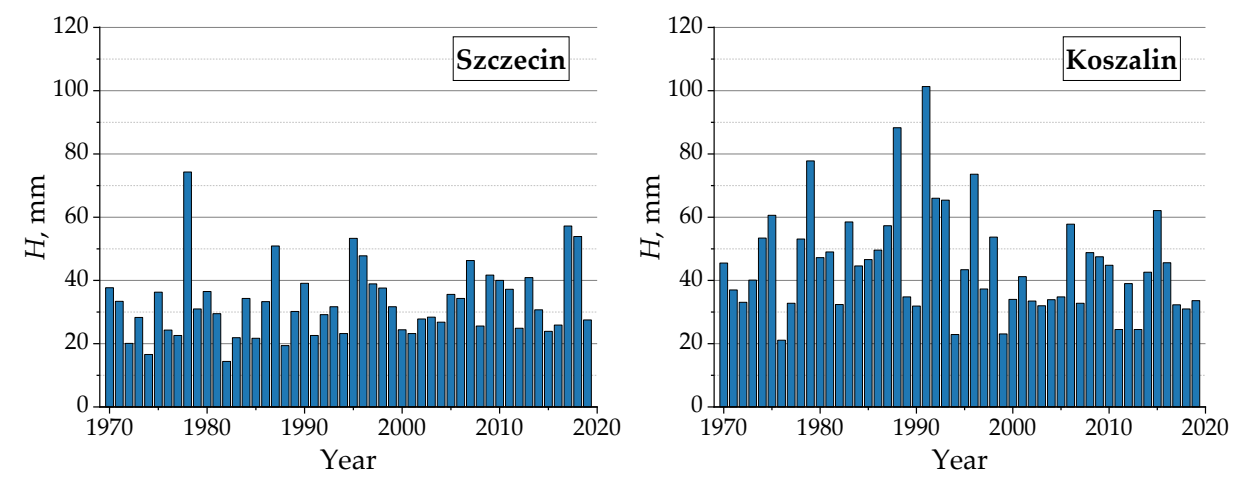

Figure 3. A set of the maximum daily precipitation amounts in Szczecin and Koszalin between 1970 and 2019. 


\subsection{Frost Day Index}

Frosty days occur in Poland especially during the winter months between December and February, and Poland's cold pole (not counting mountainous terrain) is the Suwałki region. Figure 4 shows minimum five-day temperatures recorded between 1970 and 2019 on each of the meteorological stations analysed in the paper, in the form of a heat map.

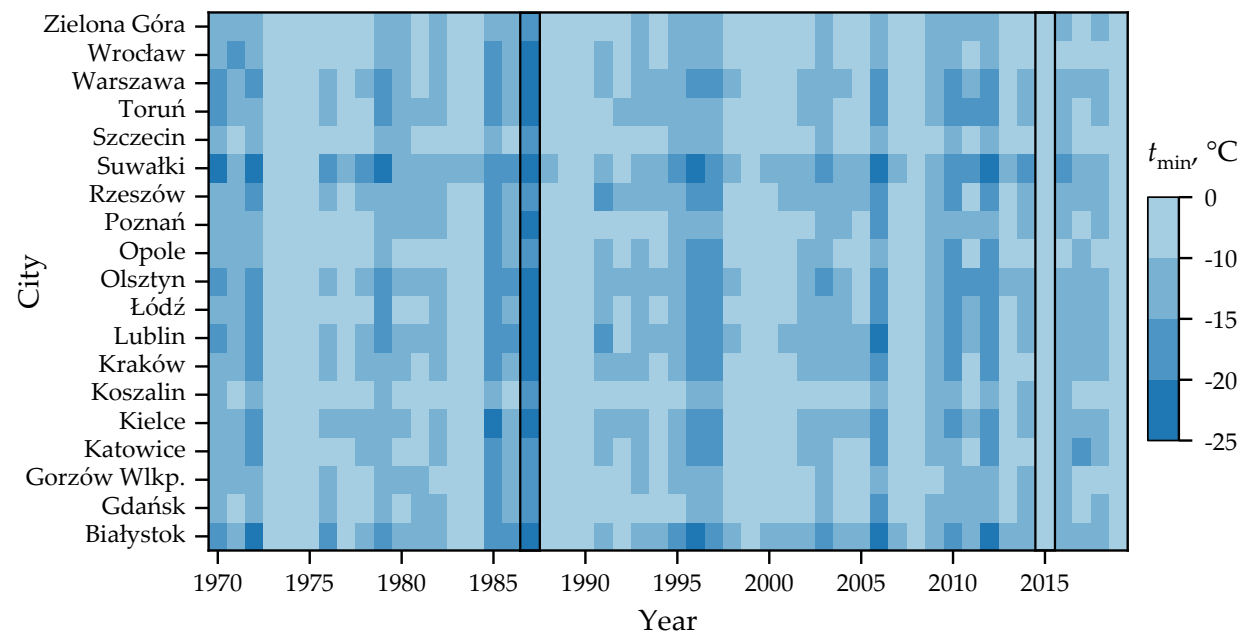

Figure 4. Minimum five-day temperatures $\left(t_{\min },{ }^{\circ} \mathrm{C}\right)$ recorded between 1970 and 2019.

In contrast with the maximum daily precipitations, a similarity can be seen between the stations in the individual years in the case of the minimum five-day temperatures. The year 1987 can be singled out, in which the average of the minimum five-day temperatures is the lowest at $-19.9{ }^{\circ} \mathrm{C}$, and the frost day index $\left(-15^{\circ} \mathrm{C}\right)$ was reached at each of the analysed localities. The highest average minimum five-day temperatures were recorded in $2015\left(-4.6^{\circ} \mathrm{C}\right)$, and the frost day index was reached in none of the analysed locations (which was also the case in 1973-1975, 1977, 1980-1984, 1988-1990, 1992-1994, 1998-2002, 2004-2005, 2007-2008, 2013, 2015, and 2018-2019).

The minimum five-day temperature (a five-day average) of only $-23.2{ }^{\circ} \mathrm{C}$ was recorded in Suwałki in 1987, whereas the maximum one (of the minimum ones), which was no fewer than $-1.4{ }^{\circ} \mathrm{C}$, was recorded in Gdańsk in 1989. In the case of each of the analysed locations, there were years during which the five-day temperature fell below the frosty day index being proposed. Such temperatures occurred the most frequently in Suwałki (28 times) and Białystok (19 times), whereas they occurred the least frequently in Koszalin, Szczecin, and Zielona Góra (2 times each). For none of the analysed locations were any statistically significant trend of change recorded in the minimum five-day temperatures (at the level of statistical significance of $95 \%$ ). The calculation results are juxtaposed in Table 2.

Table 2. Analysis of the minimum five-day temperatures between 1970 and 2019 .

\begin{tabular}{|c|c|c|c|c|c|c|}
\hline \multirow[b]{2}{*}{ City } & \multicolumn{3}{|c|}{ Minimum 5-Day Temperatures } & \multicolumn{2}{|c|}{ Trend } & \multirow{2}{*}{$\begin{array}{c}\text { Frequency of Occurrence } \\
\text { 5-Day Temperatures below }-15^{\circ} \mathrm{C}\end{array}$} \\
\hline & $\begin{array}{l}\text { Min, } \\
{ }^{\circ} \mathrm{C}\end{array}$ & $\begin{array}{l}\text { Mean, } \\
{ }^{\circ} \mathrm{C}\end{array}$ & $\underset{{ }^{\circ} \mathrm{C}}{\mathrm{Max}}$ & Yes/No & $\begin{array}{c}\text { Slope, } \\
{ }^{\circ} \text { C/Decade }\end{array}$ & \\
\hline Białystok & -22.7 & -13.3 & -5.6 & No & - & 19 \\
\hline Gdańsk & -16.9 & -8.8 & -1.4 & No & - & 4 \\
\hline Gorzów Wlkp. & -17.8 & -8.7 & -2.1 & No & - & 3 \\
\hline Katowice & -18.6 & -10.3 & -4.4 & No & - & 8 \\
\hline Kielce & -20.8 & -11.5 & -5.9 & No & - & 10 \\
\hline Koszalin & -15.2 & -7.7 & -1.9 & No & - & 2 \\
\hline Kraków & -20.3 & -11.1 & -5.2 & No & - & 10 \\
\hline Lublin & -21.0 & -12.0 & -5.8 & No & - & 14 \\
\hline Łódź & -20.7 & -10.6 & -4.8 & No & - & 11 \\
\hline Olsztyn & -22.3 & -12.0 & -3.9 & No & - & 16 \\
\hline Opole & -19.0 & -9.4 & -1.5 & No & - & 7 \\
\hline
\end{tabular}


Table 2. Cont.

\begin{tabular}{|c|c|c|c|c|c|c|}
\hline \multirow[b]{2}{*}{ City } & \multicolumn{3}{|c|}{ Minimum 5-Day Temperatures } & \multicolumn{2}{|c|}{ Trend } & \multirow{2}{*}{$\begin{array}{c}\text { Frequency of Occurrence } \\
\text { 5-Day Temperatures below }-15^{\circ} \mathrm{C}\end{array}$} \\
\hline & $\underset{{ }^{\circ} \mathrm{Cin}}{\mathrm{C}}$ & $\begin{array}{c}\text { Mean, } \\
{ }^{\circ} \mathrm{C}\end{array}$ & $\underset{{ }^{\circ} \mathrm{Cax}}{\operatorname{Max}}$ & Yes/No & $\begin{array}{c}\text { Slope, } \\
\text { C/Decade }\end{array}$ & \\
\hline Poznań & -20.1 & -9.3 & -3.2 & No & - & 6 \\
\hline Rzeszów & -19.1 & -11.5 & -5.4 & No & - & 11 \\
\hline Suwałki & -23.2 & -14.2 & -6.2 & No & - & 28 \\
\hline Szczecin & -17.1 & -7.8 & -1.9 & No & - & 2 \\
\hline Toruń & -22.3 & -10.5 & -3.5 & No & - & 12 \\
\hline Warszawa & -21.3 & -11.1 & -4.4 & No & - & 13 \\
\hline Wrocław & -20.4 & -9.2 & -1.4 & No & - & 6 \\
\hline Zielona Góra & -19.2 & -9.0 & -2.3 & No & - & 2 \\
\hline
\end{tabular}

Out of the analysed localities, it is Koszalin $\left(-7.7^{\circ} \mathrm{C}\right)$ that is distinguished by the highest average of the minimum five-day temperatures, and Suwałki $\left(-14.2^{\circ} \mathrm{C}\right)$ that is distinguished by the lowest one. A set of the minimum five-day temperatures in those cities between 1970 and 2019 is shown in Figure 5.
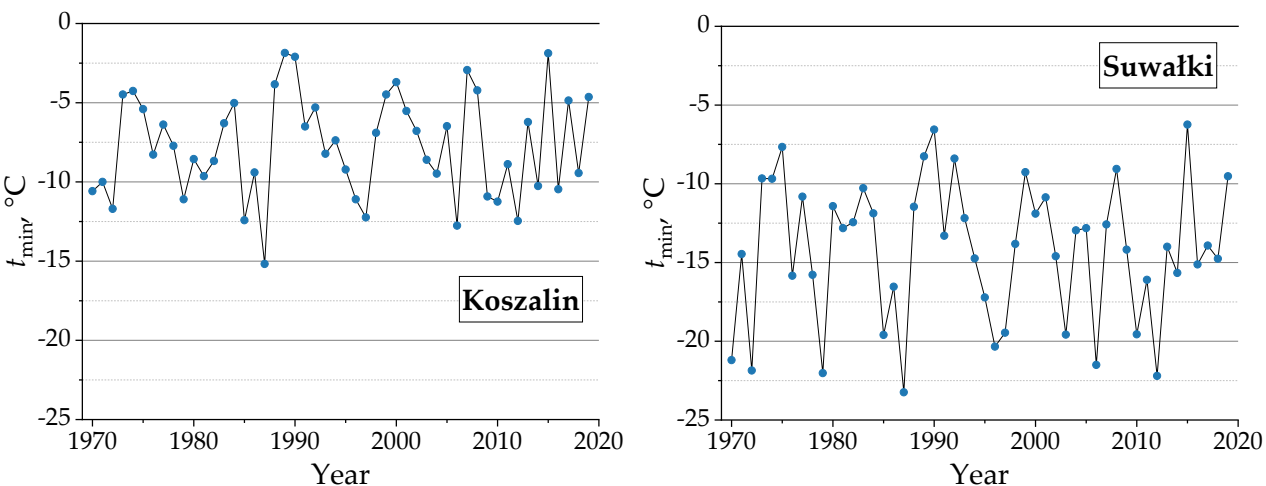

Figure 5. A set of the minimum five-day temperatures in Koszalin and Suwałki between 1970 and 2019.

\subsection{Hot Day Index}

Hot days, like the maximum precipitations, occur in Poland especially during the summer months between June and August. Figure 6 shows maximum five-day temperatures recorded between 1970 and 2019 on each of the meteorological stations analysed in the paper, in the form of a heat map.

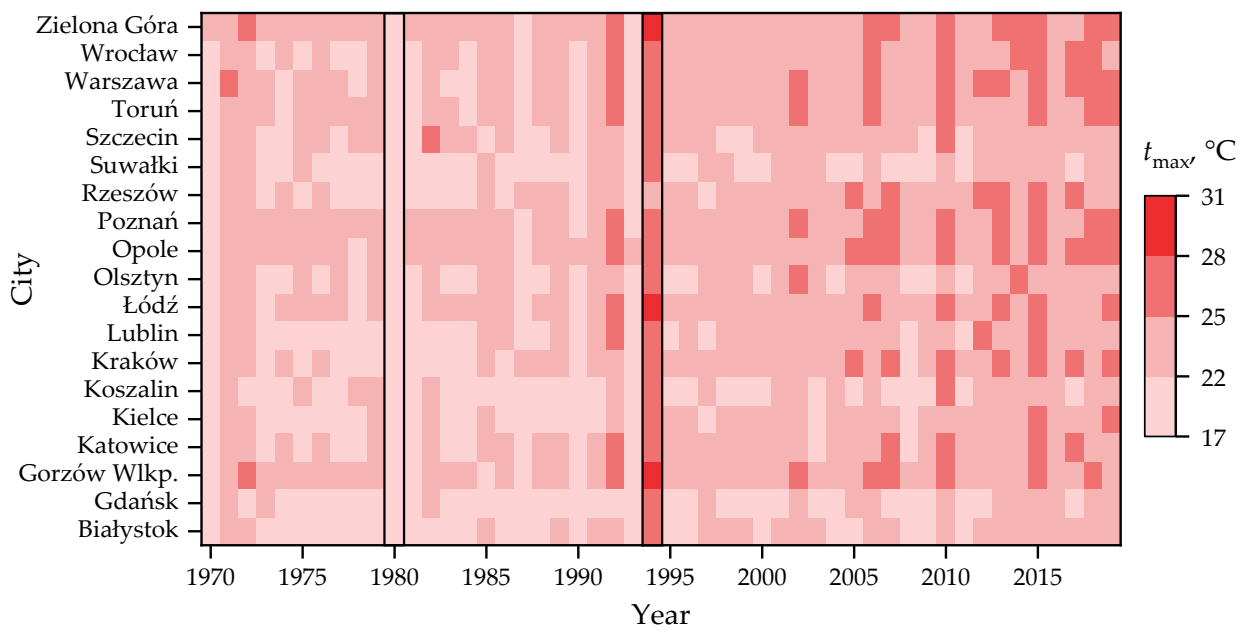

Figure 6. Maximum five-day temperatures $\left(t_{\max },{ }^{\circ} \mathrm{C}\right)$ recorded between 1970 and 2019. 
As in the case of the minimum five-day temperatures, a similarity can be seen between the stations in the individual years in the case of the maximum five-day temperatures. The year 1994 can be singled out, in which the average of the maximum five-day temperatures is the highest at no fewer than $26.7^{\circ} \mathrm{C}$, and the hot day index $\left(25^{\circ} \mathrm{C}\right)$ was reached at each of the analysed localities, except for Rzeszów. The lowest average of the maximum five-day temperatures was recorded in $1980\left(20.3^{\circ} \mathrm{C}\right)$, and the hot day index was reached at none of the analysed locations (which was also the case in 1970, 1973-1981, 1983-1991, 1993, 1995-2001, 2003-2004, 2008-2009, 2011, and 2016).

The maximum five-day temperature (a five-day average) of no fewer than $29.5^{\circ} \mathrm{C}$ was recorded in Zielona Góra in 1994, whereas the minimum one (of the minimum ones) of $17.9^{\circ} \mathrm{C}$ was recorded in Suwałki in 1987. In the case of each of the analysed locations, there were years during which the five-day temperature exceeded the hot day index being proposed. Such temperatures occurred most frequently in Opole, Warszawa, and Zielona Góra (13 times each), whereas they occurred the least frequently in Białystok, Gdańsk, and Suwałki (1 time each). It should, however, be noted that a statistically significant trend (at the level of statistical significance of 95\%) in the maximum five-day temperatures was recorded in the case of as many as 17 of the 19 analysed locations. The calculation results are juxtaposed in Table 3.

Table 3. Analysis of the maximum five-day temperatures between 1970 and 2019 .

\begin{tabular}{|c|c|c|c|c|c|c|}
\hline \multirow[b]{2}{*}{ City } & \multicolumn{3}{|c|}{ Maximum 5-Day Temperatures } & \multicolumn{2}{|c|}{ Trend } & \multirow{2}{*}{$\begin{array}{c}\text { Frequency of Occurrence } \\
\text { 5-Day Temperatures above } 25^{\circ} \mathrm{C}\end{array}$} \\
\hline & $\stackrel{\operatorname{Min},}{{ }^{\circ} \mathrm{C}}$ & $\begin{array}{l}\text { Mean, } \\
{ }^{\circ} \mathrm{C}\end{array}$ & $\stackrel{\operatorname{Max}}{{ }^{\circ} \mathrm{C}}$ & Yes/No & $\begin{array}{c}\text { Slope, } \\
{ }^{\circ} \text { C/Decade }\end{array}$ & \\
\hline Białystok & 18.5 & 22.0 & 25.2 & yes & 0.50 & 1 \\
\hline Gdańsk & 18.5 & 21.4 & 25.1 & yes & 0.39 & 1 \\
\hline Gorzów Wlkp. & 20.2 & 23.6 & 28.6 & yes & 0.41 & 10 \\
\hline Katowice & 20.6 & 23.0 & 26.5 & yes & 0.61 & 7 \\
\hline Kielce & 19.3 & 22.6 & 25.7 & yes & 0.58 & 3 \\
\hline Koszalin & 19.4 & 21.9 & 26.3 & yes & 0.33 & 2 \\
\hline Kraków & 19.9 & 22.9 & 26.5 & yes & 0.78 & 7 \\
\hline Lublin & 19.7 & 22.6 & 26.1 & yes & 0.67 & 4 \\
\hline Łódź & 19.7 & 23.4 & 28.3 & yes & 0.48 & 7 \\
\hline Olsztyn & 19.1 & 22.4 & 26.1 & yes & 0.42 & 3 \\
\hline Opole & 21.3 & 23.7 & 27.7 & yes & 0.48 & 13 \\
\hline Poznań & 20.2 & 23.7 & 26.9 & yes & 0.45 & 11 \\
\hline Rzeszów & 20.4 & 22.9 & 26.3 & yes & 0.78 & 7 \\
\hline Suwałki & 17.9 & 21.8 & 26.0 & yes & 0.57 & 1 \\
\hline Szczecin & 19.9 & 22.8 & 27.7 & no & - & 3 \\
\hline Toruń & 20.3 & 23.5 & 27.8 & yes & 0.41 & 9 \\
\hline Warszawa & 20.2 & 23.5 & 27.6 & yes & 0.63 & 13 \\
\hline Wrocław & 21.0 & 23.3 & 27.7 & yes & 0.63 & 8 \\
\hline Zielona Góra & 20.6 & 24.0 & 29.5 & no & - & 13 \\
\hline
\end{tabular}

Out of the analysed localities, it is Gdańsk $\left(21.4^{\circ} \mathrm{C}\right)$ that is distinguished by the lowest average of the maximum five-day temperatures, and Zielona Gora $\left(24.0^{\circ} \mathrm{C}\right)$ that is distinguished by the highest one. Meanwhile, in Kraków and Rzeszów, the largest increase in the maximum five-day temperatures was recorded, at a level of increase of no fewer than $0.78{ }^{\circ} \mathrm{C}$ a decade. A set of the maximum five-day temperatures in Gdańsk, Zielona Góra, Kraków, and Rzeszów between 1970 and 2019 is shown in Figure 7. 

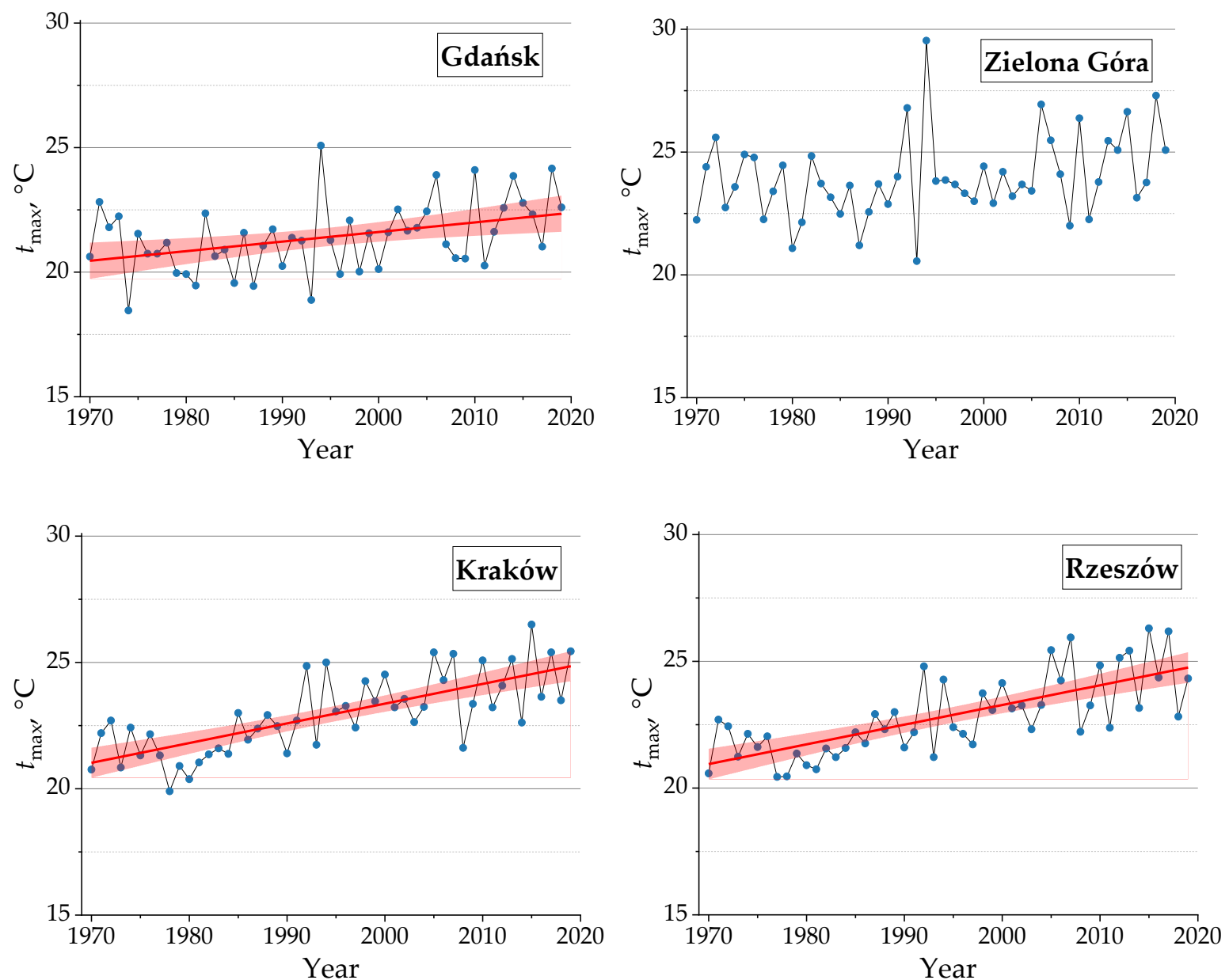

Figure 7. A set of the maximum five-day temperatures in Gdańsk, Zielona Góra, Kraków, and Rzeszów between 1970 and 2019.

\section{Discussion}

In the case of the daily precipitation index (daily precipitation exceeding $50 \mathrm{~mm}$ ), it was exceeded in the years 1970-2019 in each of 19 analysed cities, at an average of 9.5 times per 50 years, least frequently in Szczecin (5 times), Gorzów Wielkopolski, Poznań, and Warszawa (6 times each), and most frequently in Katowice, Koszalin, and Kraków (16 times each). In the case of the frost day index (5-days with temperature below $\left.-15^{\circ} \mathrm{C}\right)$, it was also exceeded in each of the 19 analysed cities, at an average of 9.7 times in 50 years, least frequently in Koszalin, Szczecin, and Zielona Góra (2 times each), and most frequently in Suwałki (28 times) and Białystok (19 times). In the case of the hot day index (5-days temperature above $25^{\circ} \mathrm{C}$ ), it was also exceeded in each of the 19 analysed cities at an average of 6.5 times in 50 years, least frequently in Białystok, Gdańsk, and Suwałki (1 time each), and most frequently in Opole, Warszawa, and Zielona Góra (13 times each). The number of cases where individual weather indices were achieved in the analysed cities in the years 1970-2019 is shown in Figure 8.

The proposed weather indexes for the water supply and sewage industry were exceeded in the past once every 6 years, on average. Obviously, due to local conditions, in some cities (Suwałki or Białystok) the frost day index was achieved much more often and the hot day index less frequently. Particular attention should be paid to the hot day index. On the one hand, they are relatively the rarest, but on the other hand, there was a clear growing trend in 17 out of 19 analysed cities. Taking into account global warming, it should be expected that the five-day temperature above $25^{\circ} \mathrm{C}$ will be reached more and more often, which is clearly shown in Figures 6 and 7. The hot day index was achieved in 
the first two decades of the 21st century much more often than in the last three decades of the 20th century (interestingly, climate warming does not affect the frequency of reaching the frost day index). Providing water supplies on hot days (usually characterised by an increased water demand) will be one of the biggest challenges for the water supply and sewage industry in Poland.

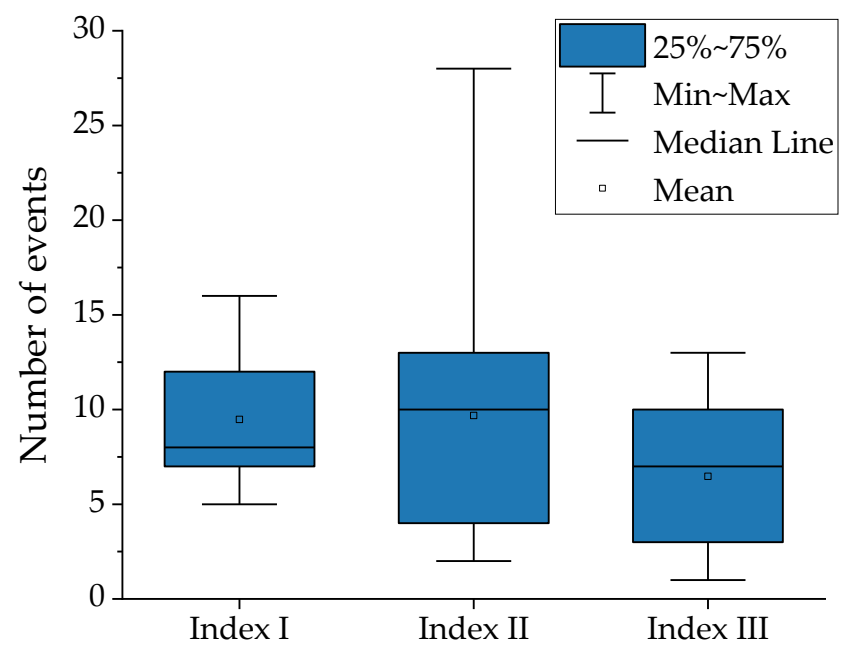

Figure 8. Number of cases with individual weather indices achieved in the years 1970-2019. Index I, daily precipitation index; Index II, frost day index; Index III, hot day index.

The results of the research indicate that, in Poland, the impact of climate change on the frequency of reaching the hot day index is noticeable, while no statistically significant change trends have been recorded for the frequency of reaching the frost day index. As these results have a national scale, it is worth comparing them with studies conducted in the worldwide literature on the climate change influence on the number of hot and frost days. Globally, an increase in the number of hot days and a decrease in the number of frost days are predicted, which is consistent with climate model projections [98]. The decrease in the number of frost days is associated with an increase in nighttime temperature, especially in winter and spring, as well as an increase in the minimum air temperature due to climate change and the effect of the urban heat island.

However, regional studies show some variation in results. The upward trends of hot days occurrence have been shown in most studies, among others for the area of Switzerland [98], Turkey [99], and Spain [100], while there are countries for which no statistically significant trend of changes was recorded, incl. for New Zealand [101], or even a slight downward trend in the number of hot days, as in China [102]. There were also mixed results in the case of frost days. In New Zealand [101], China [102], and Turkey [103] the results showed a decrease in the number of frost days (despite some local differences existing in trends). The results of studies conducted in north Iran showed an upward trend line in the western parts of the study area, while they showed a downward trend line in the eastern parts [104]. On the other hand, for the Kansas area, no statistically significant trend of changes was demonstrated [105]. It should be noted that in the studies presented in the literature it was emphasised that there was a variation in the results for individual measuring stations.

The development of the weather instruments market, due to memberships in the European Union, will probably develop dynamically in Poland as well. The weather risk becomes an incredibly significant category for many companies; however, the weather has always influenced the functioning of enterprises.

The water supply and sewerage industry in Poland is sensitive primarily to heavy rainfalls and periods of high and low temperatures. During periods with the high rainfall intensity, the phenomenon of the hydraulic overload of the rainwater drainage system 
occurs. On hot days, the water demand increases significantly, and on frost days, the risk of failure of water pipes grows. The thesis proposes three weather indices that will help to protect the interests of the water supply and sewerage industry in Poland.

It should be noted that the presented threshold values of weather indices must be determined individually for specific climatic conditions. Hence, these thresholds should be established after analysing the weather conditions in the analysed area and adapted to them. The indicators adopted in the study are based on analyses of both temperature and precipitation over several decades. The presented indices are preliminary, being a proposal for the yet undeveloped weather derivatives market in Poland, and the authors are open to a substantive discussion on this matter.

\section{Conclusions}

The paper summarises the current state of knowledge about weather risk management and proposes new weather indices for municipal companies as entities that are sensitive to weather conditions. The daily precipitation index, frost day index, and hot day index were proposed for the water and sewerage industry and verified in terms of the frequency of reaching them with the use of weather data from 1970-2019, from 19 meteorological stations across Poland. The non-parametric Mann-Kendall test was used to determine the climate change impact on the exceedance frequency of proposed indicators.

The results of this study showed that the proposed indices were exceeded in the years 1970-2019 in each of 19 analysed cities at an average of once every 6 years (the daily precipitation index, 9.5 times; the frost day index, 9.7 times; and the hot day index, 6.5 times in 50 years). The hot day index is relatively the rarest, but a clear growing trend in 17 out of 19 analysed cities was observed. The hot day index was achieved in the first two decades of the 21st century much more often than in the last three decades of the 20th century and is expected to be reached even more often in the future due to global warming. Climate change does not affect the frequency of reaching the frost day index, which is an interesting conclusion from the study.

The indicators adopted in the study were proposed based on local rainfall and temperature data, so they are appropriate for Polish weather conditions. A key challenge in the determination of weather indices is meteorological data analysis from a long period (several decades) for the analysed area and adapting the threshold values to the local climatic conditions. More studies need to be undertaken on the weather derivatives and weather indices, especially in the case of global warming, for a local, regional, and global scale.

Author Contributions: Conceptualization, J.R.R. and B.K.; methodology, J.R.R., K.W. and B.K.; formal analysis, J.R.R.; investigation, B.K.; data curation, B.K.; writing-original draft preparation, J.R.R., K.W. and B.K.; writing - review and editing, J.R.R., K.W. and B.K.; visualization, B.K.; supervision, J.R.R.; project administration, B.K. All authors have read and agreed to the published version of the manuscript.

Funding: This research received no external funding.

Institutional Review Board Statement: Not applicable.

Informed Consent Statement: Not applicable.

Data Availability Statement: Not applicable.

Conflicts of Interest: The authors declare no conflict of interest.

\section{References}

1. Michalak, D. Derywaty pogodowe jako instrument efektywnego zarzadzania ryzykiem pogodowym. Acta Innov. 2011, 1, 41-47. (In Polish)

2. Preś, J. Zarządzanie Ryzykiem Pogodowym; CeDeWu: Warsaw, Poland, 2007; p. 17. (In Polish)

3. Blachowski, D. Ryzyko pogodowe i pogodowe instrumenty pochodne w przedsiębiorstwach energetycznych. Zesz. Nauk. Unizw. Szczecińskiego Finans. Rynk. Finans. Ubezpieczenia 2011, 38, 639-648. (In Polish) 
4. Clemmons, L. Introduction to Weather Risk Management. In Weather Risk Management. Markets, Products and Applications; Banks, E., Ed.; Palgrave: New York, NY, USA, 2002; pp. 3-5.

5. WRMA/PwC. The Weather Risk Management Industry. Survey Findings for April 2001 to March 2002, June 2002. Available online: http:/ / www.wrma.org (accessed on 15 November 2020).

6. Štulec, I.; Baković, T.; Hruška, D. Weather risk management in energy sector. In Annals of DAAAM for 2012 \& Proceedings of the 23rd International DAAAM Symposium, Proceedings of the 23rd International DAAAM Symposium Intelligent Manufacturing $\mathcal{E}$ Automation: Focus on Sustainability, Zadar, Croatia, 22-28 October 2012; Katalinić, B., Ed.; DAAAM International: Vienna, Austria, 2012; pp. 89-94.

7. Smith, L.A. Integrating information, misinformation and desire: Improved weather-risk management for the energy sector. In $U K$ Success Stories in Industrial Mathematics; Aston, P.J., Mulholland, A.J., Tant, K., Eds.; Springer International Publishing: Cham, Switzerland, 2016; pp. 289-296.

8. Islip, D.; Wei, J.Z.; Kwon, R.H. Managing construction risk with weather derivatives. Eng. Econ. 2020. [CrossRef]

9. Boateng, P.; Chen, Z.; Ogunlana, S. A conceptual system dynamic model to describe the impacts of critical weather conditions in megaproject construction. J. Constr. Proj. Manag. Innov. 2012, 2, 208-224.

10. Franzoni, S.; Pelizzari, C. Weather Risk Management in Tourism Industry. Symphonya. Emerg. Issues Manag. 2016, 1, 45-55. [CrossRef]

11. Hess, U.; Richter, K.; Stoppa, A. Weather risk management for agriculture and agri-business in developing countries. In Climate Risk and the Weather Market: Financial Risk Management with Weather Hedges; Risk Books: London, UK, 2002.

12. Molarius, R.; Könönen, V.; Leviäkangas, P.; Zulkarnain; Rönty, J.; Hietajärvi, A.-M.; Oiva, K. The extreme weather risk indicators (EWRI) for the European transport system. Nat. Hazards 2014, 72, 189-210. [CrossRef]

13. Chapman, L. Weather and climate risks to road transport. Infrastruct. Asset Manag. 2015, 2, 58-68. [CrossRef]

14. Liu, L.; Wen, Y.; Liang, Y.; Zhang, F.; Yang, T. Extreme Weather Impacts on Inland Waterways Transport of Yangtze River. Atmosphere 2019, 10, 133. [CrossRef]

15. Wieczorek-Kosmala, M. Weather Risk Management in Energy Sector: The Polish Case. Energies 2020, 13, 945. [CrossRef]

16. Binkowski, P. Derywaty pogodowe-Geneza, rodzaje oraz zastosowanie. Wspótczesna Ekon. 2008, 2, 47-68. (In Polish)

17. Michalak, D. Analysis of weather risk in agriculture as an important part of adaptation to climate change. Ekon. Sr. 2016, 2, 75-91.

18. Pawłowski, J. Pogodowe instrumenty pochodne-Możliwości zawarcia transakcji na przykładzie producentów wody butelkowanej w Polsce. Acta Univ. Lodziensis Folia Oeconomica 2014, 2, 203-213. (In Polish)

19. Czekaj, Z. Derywaty pogodowe jako instrument zarządzania ryzykiem pogodowym. Ruch Praw. Ekon. Soc. Jologiczny 2016, 78, 217-228. (In Polish) [CrossRef]

20. Solaun, K.; Cerdá, E. The Impact of Climate Change on the Generation of Hydroelectric Power-A Case Study in Southern Spain. Energies 2017, 10, 1343. [CrossRef]

21. Creutzig, F.; Agoston, P.; Goldschmidt, J.C.; Luderer, G.; Nemet, G.; Pietzcker, R.C. The underestimated potential of solar energy to mitigate climate change. Nat. Energy 2017, 2. [CrossRef]

22. Waite, M.; Cohen, E.; Torbey, H.; Piccirilli, M.; Tian, Y.; Modi, V. Global trends in urban electricity demands for cooling and heating. Energy 2017, 127, 786-802. [CrossRef]

23. Canales, F.A.; Jadwiszczak, P.; Jurasz, J.; Wdowikowski, M.; Ciapała, B.; Kaźmierczak, B. The impact of long-term changes in air temperature on renewable energy in Poland. Sci. Total. Environ. 2020, 729. [CrossRef]

24. Ray, A.; Hughes, L.; Konisky, D.M.; Kaylor, C. Extreme weather exposure and support for climate change adaptation. Glob. Environ. Chang. 2017, 46, 104-113. [CrossRef]

25. Guthrie, G. Real options analysis of climate-change adaptation: Investment flexibility and extreme weather events. Clim. Chang. 2019, 156, 231-253. [CrossRef]

26. Dell, M.L.; Jones, B.F.; Olken, B.A. What Do We Learn from the Weather? The New Climate-Economy Literature. J. Econ. Lit. 2014, 53, 740-798. [CrossRef]

27. Schneider, S.H.; Lane, J. An Overview of ‘Dangerous' Climate Change. In Avoiding Dangerous Climate Change; Schellnhuber, H.J., Cramer, W., Nakicenovic, N., Wigley, T., Yohe, G., Eds.; Cambridge University Press: Cambridge, UK, 2006 ; pp. 7-23.

28. Klimat ryzyka. Available online: https://nawypadekgdy.pl/wp-content/uploads/2018/12/181212_PIU_raport-klimatyczny.pdf (accessed on 20 October 2020).

29. Ruff, T.W.; Neelin, J.D. Long tails in regional surface temperature probability distributions with implications for extremes under global warming. Geophys. Res. Lett. 2012, 39. [CrossRef]

30. Campbell, S.D.; Diebold, F.X. Weather Forecasting for Weather Derivatives. J. Am. Stat. Assoc. 2005, 100, 6-16. [CrossRef]

31. Alaton, P.; Djehiche, B.; Stillberger, D. On modelling and pricing weather derivatives. Appl. Math. Financ. 2002, 9. [CrossRef]

32. Liu, X. Weather Derivatives: A Contemporary Review and its Application in China. Ph.D. Thesis, University of Nottingham, Nottingham, UK, 2006.

33. Ustawa z dnia 18 kwietnia 2002 r. o stanie klęski żywiołowej (Dz.U. 2002 Nr 62 poz. 558). (In Polish). Available online: http:/ / isap.sejm.gov.pl/isap.nsf/download.xsp/WDU20020620558/U/D20020558Lj.pdf (accessed on 10 October 2020).

34. Ustawa z Dnia 26 Kwietnia 2007 Roku o Zarządzaniu Kryzysowym (Dz.U. z 2007 r. nr 89, poz.590 ze zm.). (In Polish). Available online: http:/ /isap.sejm.gov.pl/isap.nsf/download.xsp/WDU20070890590/U/D20070590Lj.pdf (accessed on 10 October 2020). 
35. Konstytucja Rzeczypospolitej Polskiej z Dnia 2 Kwietnia 1997 Roku (Dz. U. z 1997 r. Nr 78, poz. 483). (In Polish). Available online: http:/ /isap.sejm.gov.pl/isap.nsf/download.xsp/WDU19970780483/U/D19970483Lj.pdf (accessed on 10 October 2020).

36. Bac, M. Ryzyko katastroficzne jako przedmiot regulacji w ustawodawstwie polskim. In Ubezpieczenia Gospodarcze i Społeczne: Wybrane Zagadnienia Ekonomiczne; Sułkowska, W., Ed.; Wolters Kluwer: Warsaw, Poland, 2011; pp. 11-25. (In Polish)

37. Ustawa z Dnia 21 Czerwca 2002 Roku o Stanie Wyjatkowym (Dz.U. z 2002 r. nr 113, poz. 985 ze zm.). (In Polish). Available online: http:/ /isap.sejm.gov.pl/isap.nsf/download.xsp/WDU20021130985/U/D20020985Lj.pdf (accessed on 10 October 2020).

38. Ustawa z Dnia 22 Listopada 2002 Roku o Wyrównaniu Strat Majątkowych Wynikających z Ograniczenia w Czasie Stanu Nad-zwyczajnego Wolności Praw Człowieka i Obywatela (Dz.U. z 2002 r. nr 233, poz. 1955). (In Polish). Available online: http:/ / isap.sejm.gov.pl/isap.nsf/download.xsp/WDU20022331955/O/D20021955.pdf (accessed on 10 October 2020).

39. Ustawa z Dnia 22 Sierpnia 2001 Roku o Bezpieczeństwie Imprez Masowych (Dz.U. z 2005 r. nr 108, poz. 909 ze zm.). (In Polish). Available online: https:/ / eli.gov.pl/api/acts/DU/1997/680/text/I/D19970680.pdf (accessed on 10 October 2020).

40. Ustawa z Dnia 18 Lipca 200 Roku-Prawo Wodne (Dz.U. z 2005 r. nr 239, poz. 2019 ze zm.). (In Polish). Available online: http:/ / isap.sejm.gov.pl/isap.nsf/download.xsp/WDU20011151229/U/D20011229Lj.pdf (accessed on 10 October 2020).

41. Dekret z Dnia 23 Kwietnia 1953 Roku o Swiadczeniach w Celu Zwalczania Klęsk Zywiołowych (Dz.U. z 1953 r. nr 23 , poz. 93 ze zm.). (In Polish). Available online: https:/ / eli.gov.pl/eli/DU/1953/93/ogl/pol (accessed on 10 October 2020).

42. Ustawa z Dnia 24 Sierpnia 1991 Roku o Ochronie Przeciwpożarowej (Dz.U. z 1991 r. nr 81, poz. 351 ze zm.). (In Polish). Available online: http:/ /isap.sejm.gov.pl/isap.nsf/download.xsp/WDU19910810351/U/D19910351Lj.pdf (accessed on 10 October 2020).

43. Ustawa z Dnia 8 Września 2006 Roku o Państwowym Ratownictwie Medycznym (Dz.U. z 2006 r. nr 191, poz. 1410 ze zm.). (In Polish). Available online: http:/ / eli.sejm.gov.pl/eli/DU/2006/1410/ogl (accessed on 10 October 2020).

44. Ustawa z Dnia 27 Kwietnia 2001 Roku-Prawo Ochrony Środowiska (Dz.U. z 2001 r. nr 62, poz. 627). (In Polish). Available online: http:/ /isap.sejm.gov.pl/isap.nsf/download.xsp/WDU20010620627/U/D20010627Lj.pdf (accessed on 10 October 2020).

45. Rozporządzenie Rady Ministrów z Dnia 20 Lutego 2003 Roku w Sprawie Szczegółowych Zasad Udziału Pododdziałów i Oddziałów Sił Zbrojnych Rzeczypospolitej Polskiej w Zapobieganiu Skutkom Klęski Zywiołowej lub ich Usuwaniu (Dz.U. z 2003 r. nr 41, poz. 347). (In Polish). Available online: http:/ / eli.sejm.gov.pl/eli/DU/2003/347/ogl (accessed on 10 October 2020).

46. Brockett, P.L.; Wang, M.; Yang, C. Weather Derivatives and Weather Risk Management. Risk Manag. Insur. Rev. 2005, 8, 127-139. [CrossRef]

47. Burchard-Dziubińska, M. Ryzyko pogodowe na rynku ubezpieczeń. Ekon. XXI Wieku 2016, 12, 46-56. (In Polish)

48. Prewysz-Kwinto, P. Pogodowe instrumenty pochodne. In Innowacje na Rynkach Finansowych; CeDeWu: Warsaw, Poland, 2010; pp. 21-34. (In Polish)

49. Szopa, A. Właściwości ryzyka pogodowego. Ann. Univ. Mariae Curie Skłodowska Sect. H Oeconomia 2012, 46, 445-452. (In Polish)

50. United Nations General Assembly. The Sendai Framework for Disaster Risk Reduction 2015-2030. Resolution A/Res/69/283. Available online: https:/ / www.unisdr.org/files/43291_sendaiframeworkfordrren.pdf (accessed on 30 October 2020).

51. Wahlström, M. New Sendai Framework Strengthens Focus on Reducing Disaster Risk. Int. J. Disaster Risk Sci. $2015,6,200-201$. [CrossRef]

52. United Nations. Transforming our World: The 2030 Agenda for Sustainable Development. Available online: https://www.un. $\mathrm{org} / \mathrm{ga} / \mathrm{search} /$ view_doc.asp?symbol=A/RES/70/1\&Lang=E (accessed on 19 October 2020).

53. ADMS-Agricultural Drought Monitoring System. Available online: http://www.susza.iung.pulawy.pl/ (accessed on 20 October 2020).

54. Ratajewska, A. Aspekt bezpieczeństwa w planowaniu terenów zagrożonych powodzią. Tech. Issues 2016, 4, 68-77. (In Polish)

55. Development of Urban Adaptation Plans for Cities with More than 100,000 Inhabitants in Poland. Available online: http: / /44mpa.pl/miejskie-plany-adaptacji/ (accessed on 20 October 2020).

56. Geman, H.; Leonardi, M.P. Alternative approaches to weather derivatives pricing. Manag. Finance 2005, 31, 46-72. [CrossRef]

57. Cui, H.; Zhou, Y.; Dzandu, M.D.; Tang, Y.; Lu, X. Is temperature-index derivative suitable for China? Phys. A Stat. Mech. Appl. 2019, 536. [CrossRef]

58. Cabrera, B.L.; Odening, M.; Ritter, M. Pricing rainfall futures at the CME. J. Bank. Finance 2013, 37, 4286-4298. [CrossRef]

59. Cramer, S.; Kampouridis, M.; Freitas, A.A.; Alexandridis, A. Stochastic model genetic programming: Deriving pricing equations for rainfall weather derivatives. Swarm Evol. Comput. 2019, 46, 184-200. [CrossRef]

60. Mentel, G. Wartość Zagrożona Jako Instrument Zarządzania Ryzykiem Pogodowym; Oficyna Wydawnicza Politechniki Rzeszowskiej: Rzeszów, Poland, 2017. (In Polish)

61. Stulz, R.M. Should We Fear Derivatives? J. Econ. Perspect. 2004, 18, 173-192. [CrossRef]

62. Banks, E. Weather Fundamentals. In Weather Risk Management. Markets, Products and Applications; Banks, E., Ed.; Palgrave: New York, NY, USA, 2002.

63. Michalak, D. Charakterystyka derywatów pogodowych wraz z opisem wykorzystania instrumentu w Polsce i na świecie. Ekonomia 2013, 22, 73-85. (In Polish)

64. Rajani, B.; Kleiner, Y.; Sink, J.-E. Exploration of the relationship between water main breaks and temperature covariates. Urban Water J. 2012, 9, 67-84. [CrossRef]

65. Shamir, U.; Howard, C.D.D. An Analytic Approach to Scheduling Pipe Replacement. J. AWWA 1979, 71, 248-258. [CrossRef]

66. Goulter, I.C.; Davidson, J.; Jacobs, P. Predicting water-main breakage rates. J. Water Resour. Plan. Manag. 1993, 119, 419-436. [CrossRef] 
67. Le Gat, Y.; Eisenbeis, P. Using maintenance records to forecast failures in water networks. Urban Water 2000, 3, 173-181. [CrossRef]

68. Rak, J. Safety of Water Supply System; Polish Academy of Science: Warsaw, Poland, 2009.

69. Tchórzewska-Cieślak, B.; Pietrucha-Urbanik, K.; Urbanik, M. Analysis of the gas network failure and failure prediction using the Monte Carlo simulation method. Ekspolatacja Niezawodn. Maint. Reliab. 2016, 18, 254-259. [CrossRef]

70. Bhattarai, J. Study on the Corrosive Nature of Soil Towards the Buried-Structures. Sci. World 2013, 11, 43-47. [CrossRef]

71. Gould, S.J.F.; Boulaire, F.A.; Burn, S.; Zhao, X.L.; Kodikara, J.K. Seasonal factors influencing the failure of buried water reticulation pipes. Water Sci. Technol. 2011, 63, 2692-2699. [CrossRef]

72. Harada, H. Statistics of the cold wave in the temperate region and prediction of the number of damaged service pipes. J. AWWA 1988, 57, 12-15.

73. Wols, B.A.; Van Thienen, P. Impact of weather conditions on pipe failure: A statistical analysis. J. Water Supply: Res. Technol. 2014, 63, 212-223. [CrossRef]

74. Barton, N.A.; Farewell, T.S.; Hallett, S.H.; Acland, T.F. Improving pipe failure predictions: Factors affecting pipe failure in drinking water networks. Water Res. 2019, 164. [CrossRef]

75. Farmani, R.; Kakoudakis, K.; Behzadian, K.; Butler, D. Pipe Failure Prediction in Water Distribution Systems Considering Static and Dynamic Factors. Procedia Eng. 2017, 186, 117-126. [CrossRef]

76. Bruaset, S.; Sægrov, S. An Analysis of the Potential Impact of Climate Change on the Structural Reliability of Drinking Water Pipes in Cold Climate Regions. Water 2018, 10, 411. [CrossRef]

77. Rajani, B.; Tesfamariam, S. Uncoupled axial, flexural, and circumferential pipe-soil interaction analyses of partially supported jointed water mains. Can. Geotech. J. 2004, 41, 997-1010. [CrossRef]

78. Walski, T.M.; Pelliccia, A. Economic analysisof water main breaks. J. Am. Water Works Ass. 1982, 74, 140-147. [CrossRef]

79. Pietrucha-Urbanik, K.; Żelazko, A. Approaches to Assess Water Distribution Failure. Period. Polytech. Civ. Eng. 2017, 61, 632-639. [CrossRef]

80. Pietrucha-Urbanik, K. Failure analysis and assessment on the exemplary water supply network. Eng. Fail. Anal. 2015, 57, 137-142. [CrossRef]

81. Newport, R. Factors influencing the occurrence of bursts in iron water mains. Water Supply Manage. 1981, 3, $274-278$.

82. Kleiner, Y.; Rajani, B. Forecasting variations and trends inwater-main breaks. J. Infrastruct. Syst. 2002, 8, 122-131. [CrossRef]

83. $\mathrm{Hu}, \mathrm{Y}$;; Hubble, D.W. Factors contributing to the failure of asbestos cement water mains. Can. J. Civ. Eng. 2007, 34, 608-621. [CrossRef]

84. Laucelli, D.B.; Rajani, B.; Kleiner, Y.; Giustolisi, O. Study on relationships between climate-related covariates and pipe bursts using evolutionary-based modelling. J. Hydroinformatics 2013, 16, 743-757. [CrossRef]

85. Kuliczkowska, E. Risk of structural failure in concrete sewers due to internal corrosion. Eng. Fail. Anal. 2016, 66, 110-119. [CrossRef]

86. Pomeroy, R.D. Sanitary Sewer Design for Hydrogen Sulphide Control. Public Work. 1970, 101, 93-96.

87. Buchert, L.; Cebulak, E.; Drwal-Tylmann, A.; Wojtczak-Gaglik, E.; Kilar, P.; Limanówka, D.; Łapińska, E.; Mizera, M.; Ogórek, S.; Pyrc, R.; et al. Vademecum: Niebezpieczne Zjawiska Meteorologiczne, Geneza, Skutki, Częstość Występowania, Część Pierwsza-Wiosna, Lato; IMGW-PIB: Warsaw, Poland, 2013. (In Polish)

88. Wartalska, K.; Kaźmierczak, B.; Nowakowska, M.; Kotowski, A. Precipitation patterns for modeling land drainage in Poland. Urban Water J. 2020, 17, 333-343. [CrossRef]

89. Żywiec, J.; Piegdoń, I.; Tchórzewska-Cieślak, B. Failure analysis of the water supply network in the aspect of climate changes on the example of the Central and Eastern Europe region. Sustainability 2019, 11, 6886. [CrossRef]

90. Kutyłowska, M. Forecasting failure rate of water pipes. Water Supply 2019, 19, 264-273. [CrossRef]

91. Dawidowicz, J.; Czapczuk, A.; Piekarski, J. The application of artificial neural networks in the assessment of pressure losses in water pipes in the design of water distribution systems. Rocz. Ochr. Sr. 2018, 20, 292-308.

92. Canales, F.A.; Gwoździej-Mazur, J.; Jadwiszczak, P.; Struk-Sokołowska, J.; Wartalska, K.; Wdowikowski, M.; Kaźmierczak, B. Long-term trends in 20-day cumulative precipitation for residential rainwater harvesting in Poland. Water 2020, $12,1932$. [CrossRef]

93. Ali, R.; Ismael, A.; Heryansyah, A.; Nawaz, N. Long Term Historic Changes in the Flow of Lesser Zab River, Iraq. Hydrology 2019, 6, 22. [CrossRef]

94. Langat, P.K.; Kumar, L.; Koech, R. Temporal Variability and Trends of Rainfall and Streamflow in Tana River Basin, Kenya. Sustainability 2017, 9, 1963. [CrossRef]

95. Arrieta-Castro, M.; Donado-Rodríguez, A.; Acuña, G.J.; Canales, F.A.; Teegavarapu, R.S.V.; Kaźmierczak, B. Analysis of Streamflow Variability and Trends in the Meta River, Colombia. Water 2020, 12, 1451. [CrossRef]

96. Jaiswal, R.K.; Lohani, A.K.; Tiwari, H.L. Statistical Analysis for Change Detection and Trend Assessment in Climatological Parameters. Environ. Process. 2015, 2, 729-749. [CrossRef]

97. Wijngaard, J.B.; Tank, A.K.; Können, G.P. Homogeneity of 20th century European daily temperature and precipitation series. Int. J. Clim. 2003, 23, 679-692. [CrossRef]

98. Scherrer, S.C.; Fischer, E.M.; Posselt, R.; Liniger, M.A.; Croci-Maspoli, M.; Knutti, R. Emerging trends in heavy precipitation and hot temperature extremes in Switzerland. J. Geophys. Res. Atmos. 2016, 121, 2626-2637. [CrossRef] 
99. Erlat, E.; Türkeş, M. Observed changes and trends in numbers of summer and tropical days, and the 2010 hot summer in Turkey. Int. J. Clim. 2013, 33, 1898-1908. [CrossRef]

100. García-Valero, J.A.; Montávez, J.P.; Gómez-Navarro, J.J.; Jiménez-Guerrero, P. Attributing trends in extremely hot days to changes in atmospheric dynamics. Nat. Hazards Earth Syst. Sci. 2015, 15, 2143-2159. [CrossRef]

101. Salinger, M.J.; Griffiths, G.M. Trends in New Zealand daily temperature and rainfall extremes. Int. J. Clim. 2001, 21, 1437-1452. [CrossRef]

102. Zhai, P.; Pan, X. Trends in temperature extremes during 1951-1999 in China. Geophys. Res. Lett. 2003, 30. [CrossRef]

103. Erlat, E.; Türkeş, M. Analysis of observed variability and trends in numbers of frost days in Turkey for the period 1950-2010. Int. J. Clim. 2012, 32, 1889-1898. [CrossRef]

104. Biazar, S.M.; Ferdosi, F.B. An investigation on spatial and temporal trends in frost indices in Northern Iran. Theor. Appl. Clim. 2020, 141, 907-920. [CrossRef]

105. Anandhi, A.; Perumal, S.; Gowda, P.H.; Knapp, M.; Hutchinson, S.; Harrington, J.; Rice, C.W. Long-term spatial and temporal trends in frost indices in Kansas, USA. Clim. Chang. 2013, 120, 169-181. [CrossRef] 